Agnieszka Hamerlińska* (D), Jacek J. Błeszyński** (D) Jerzy Rottermund ${ }^{* * *}$ (DD, Andrzej Knapik**** (D)

\title{
Therapeutic Recommendations for Caregivers of People with Dysphagia
}

Zalecenia terapeutyczne dla opiekunów osób z dysfagią

\author{
Keywords: family, disability, dysphagia, therapy \\ Słowa kluczowe: rodzina, niepełnosprawność, dysfagia, terapia
}

\section{Introduction}

Eating is one of the most important activities of people from the beginning of their life. Feeding, and consequently gaining weight, is the most important factor in the neonatal period and infancy. Appetite in a child is perceived as a desirable phenomenon. The same refers to people who are ill and their willingness to eat is interpreted as coming back to health.

The topic of eating is interdisciplinary. It seems that the very act of eating is simple, quick and pleasant. Yet this is a very complex activity combining the physical, mental and social sphere. The anatomy and functionality of organs responsible for

\footnotetext{
* Nicolaus Copernicus University in Toruń, Faculty of Philosophy and Social Sciences, Institute of Pedagogical Sciences, 11 Gagarina street, 87-100 Toruń, e-mail: hamer@umk.pl, ORCID: https://orcid .org/0000-0002-9305-5793.

* Nicolaus Copernicus University in Toruń, Faculty of Philosophy and Social Sciences, Institute of Pedagogical Sciences, 11 Gagarina street, 87-100 Toruń, e-mail: jjbleszynski@gmail.com, ORCID: https://orcid.org/0000-0002-6553-0550.

*** St. Elizabeth University of Health and Social Work, Námestie 1. mája 1, P.O. BOX 104810 00, Bratislava, Slovakia, e-mail: jerzy_rottermund@op.pl, ORCID: https://orcid.org/0000-0002-9629-7800.

**** Medical University of Silesia in Katowice, School of Health Sciences in Katowice, Chair of Physiotherapy, Department of Adapted Physical Activity and Sport, 15 Poniatowskiego street, 40-055 Katowice, e-mail: aknapik@o2.pl, ORCID: https://orcid.org/0000-0002-6946-9312.
} 
eating are essential in this process. A suitable diet is also important as well as the role of eating in everyday life, particularly in family life.

Eating food on an independent basis can be difficult in a situation of illness or disability. In such a situation assistance is necessary on the part of family members. It happens that family members are unprepared for this and they find it difficult to adapt to it. They do not know how to help, give food and what feeding position the patient should assume. It is often necessary to change the diet, the food served must have different consistency, some products have to be eliminated. What is more, it is necessary to use other, better adjusted tools: a flat spoon, a less sharp fork or a mug with a special straw.

The aim of the paper is to indicate those activities which may help family members taking care of patients with dysphagia.

\section{Dysphagia, or swallowing disorder, as one of the symptoms accompanying disability}

Dysphagia refers to eating and/or swallowing disorders. It is not connected, however, with psychiatric disorders as it is the case in anorexia, bulimia or obesity. The problem of dysphagia is dealt with by doctors with different specializations, such as neurologists, gastrologists, laryngologists, oncologists as well as physiotherapists and speech therapists. While writing about dysphagia it is necessary to draw attention to their causes: functional disorders (neuroses, esophagitis), neurological disorders (lesion of centres which coordinate swallowing) and mechanical disorders (stricture or closure of the esophageal lumen by a cancer or a foreign body) [Klukowski, Nowotny, Czamara, 2014; cf. Narożny, Szmaj, 2014]. Difficulties in eating may occur at any age and they may be due to several overlapping causes or a single cause.

In order to understand swallowing disorders it is necessary to know the different stages of eating. Eating is dependent, among other things, on the amount of food introduced at a time, the pace of eating or the skill of moving the bolus from the anterior part of the oral cavity to the stomach in a coordinated way. An important element, particularly in children (but not only), is due care during feeding or eating food on an independent basis.

Medical sciences use the division into three stages: the preparatory and proper oral phase, the pharyngeal phase and the esophageal stage [Gadowska-Cicha, Sieron, Cak, 2004]. In speech therapy there is the additional pre-oral prep phase which allows to check if the patient is able to adjust the kind of food to his swallowing abilities on his own [Hamerlińska-Latecka, 2013]. Subsequently, the first oral stage begins (the oral preparatory phase) which consists of closing the lips, movements of the mandible and the tongue, tightening of the cheeks as well as movement of the anterior palate. Food or liquid mixes with saliva in the anterior part of the oral cavity, 
creating a bolus. Elevation of the tongue causes the content to move inside the oral cavity (the proper oral phase). At this point the pharynx begins to react. There are sensory receptors of taste, temperature and bolus volume of the bolus in the pharynx. The pharyngeal stage (the throat stage) begins, including closing the entrance to the nasal cavity (contraction of the superior pharyngeal constrictor muscle innervated by the vagus nerve). Subsequently, the bolus is pushed in the direction of the esophagus as a result of the contraction of the pharynx and the swallowing phase begins. At this stage it is necessary to protect the upper respiratory tract from food contents. This defensive mechanism consists in shutting the vocal folds, inverting the epiglottis and elevating the larynx. Finally, the bolus reaches the stomach [Ganesh, Janakiraman, Sathiyasekaran, 2008; Riquelme et al., 2008; Boksa, 2016] (Picture 1).

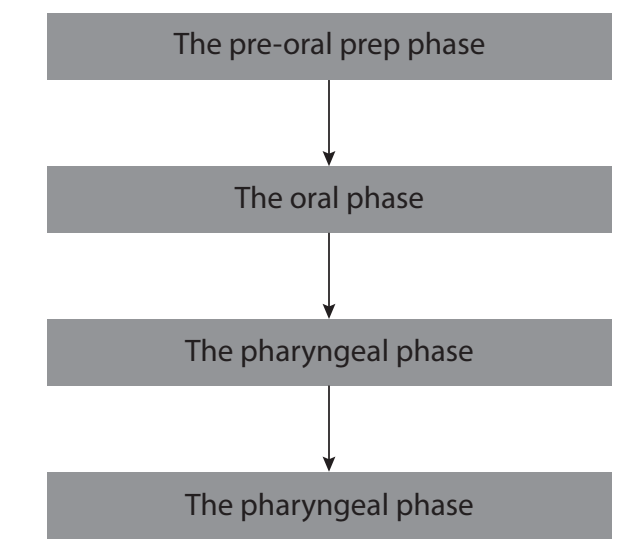

Picture 1. Stages of swallowing

Source: Hamerlińska-Latecka, Wójcik, Pyszora, 2013, p. 129.

A person with dysphagia may have problems with taking the food, keeping it in the oral cavity, forming the food into a bolus, then transporting the food inside the oral cavity to the pharynx and later through the esophagus to the stomach. Difficulty in swallowing may occur in each section of the digestive tract. Patients with dysphagia have difficulty primarily in swallowing liquids and then solid food. Even small bites are lodged in the cheeks, many a time already in the phase of chewing. Dysphagia may be manifested by coughing, choking, gag reflexes, lacrimation, sneezing, pain on swallowing and the feeling of retaining food in the esophagus. Eating food becomes increasingly onerous, patients are unwilling to eat and they eat less and less. One symptom observed in patients with dysphagia is choking during the meal as an effect of excessive filling of the oral cavity with the food content or delayed collapse of the pharynx when the food may enter the upper respiratory tract. It is worth stressing, however, that expectoration and cough are a natural physiological reaction and at the same time an attempt to clear the respiratory tract [Riquelme et al., 2016]. Dysphagia as an effect of different dysfunctions may result in malnutrition and 
dehydration, which are dangerous for the proper functioning of the organism. This is why the readiness to assist in receiving and swallowing liquids and food by patients is so important for both carers and therapists.

\section{Selected diseases and dysphagia}

Many disease entities are accompanied by dysphagia and often enough there are several causes of that. Difficulties in eating solids and liquids may occur in all decades of life, from infancy to very old age. This publication presents only selected diseases accompanied by dysphagia ${ }^{1}$.

In the case of patients with infantile cerebral palsy (ICP) two aspects should be discussed: feeding and swallowing disorders. The nature of the disorders and frequency of their occurrence are closely connected with the degree of the dysfunction, limitations with regard to gross and fine motor skills as well as co-occurring intellectual disability [Arvedson et al., 2013]. Damage to the central and/or peripheral nervous system in infants causes delay in acquiring eating skills and the feeding time increases. Neurogenic dysphagia is diagnosed in children with ICP [Litwin, 2009], these children tend to gain weight too slowly and their health problems are exacerbated by recurrent upper respiratory infections.

Calis et al. [2008] examined children with infantile cerebral palsy and intellectual disability using the Dysphagia Disorder Survey (elaborated by Sheppard in 2002) in order to assess the presence, characteristics and severity of dysphagia. Of all participating children, $76 \%$ had moderate to severe dysphagia and $15 \%$ profound dysphagia. The occurrence of dysphagia did not correlate with the opinion of the examined children's parents on eating difficulty [Calis et al., 2008]. This observation seems essential as it gives an idea of the fact that not all parents (and perhaps also carers and therapists) are aware of feeding problems in children. Symptoms which facilitate diagnosis and may suggest neurogenic dysphagia in children with ICP include [Przeździęk, 2016]:

- limited or/and incomplete closure of the lips on the spoon or cup causing the liquid to flow out of the mouth;

- retention of food on the tongue (there are food remains on the tongue after swallowing);

- pocketing food in the oral cavity and long time of forming the bolus;

- delayed swallowing reflex;

- swallowing small portions, with great effort and simultaneous neck muscle tension;

1 A subjective selection of disorders with which dysphagia coexists was made. It results from many years of cooperation in physiotherapy and speech therapy and observation indicating that people with the above-mentioned diseases are undergoing dysphagia therapy. 
- choking while eating and coughing, clearing one's throat after the meal;

- passage of food to the nasal cavity due to insufficient palatopharyngeal closure;

- retention of food leftovers in pyriform sinuses due to weakening of the movements of the larynx and hoarseness after the meal;

- aspiration of food to the respiratory tract which may cause aspiration pneumonia;

- frequent pneumonia and/or bronchitis (recurrent infections of the upper and/ or lower respiratory tract;

- fear of eating and weight loss;

- cough or fever of unknown etiology.

Difficulties in eating (feeding, swallowing) are present in $80 \%$ children with delayed development [Bryant-Waugh et al., 2010], in $90 \%$ of those with autism [Ahearn, 2001] and in premature babies. There are several reasons for that, they may differ with regard to their etiology or severity. They include lack of motivation and motor skills, such as sucking, chewing and swallowing [Hoch, Babbitt, Farrar-Schneider, 2001]. Patients with feeding difficulties include patients with neurological disorders, gastrointestinal diseases (food allergies, reflux disease) and its anomalies (esophageal stenosis, cleft palate) as well as in patients with metabolic diseases [Chatoor, 2002]. At the same time it is necessary to distinguish food allergies (conditioned by immune mechanisms) from food intolerance resulting from non-immune mechanisms.

Another cause of dysphagia is cerebral stroke, it occurs in the case of $37-78 \%$ of all strokes [Januś-Laszuk et al., 2012]. The paresis of the face and tongue accompanying the stoke exacerbates difficulties in feeding [Starosta et al., 2016]. Difficulties in swallowing solid food and drinking an appropriate amount of liquids result in malnutrition and dehydration of patients, at the same time posing the threat of aspiration pneumonia as a risk factor for death or another disability. It should be mentioned at this point that cerebral stroke also occurs in children, yet far less frequently. The consequences are identical as in adults. The biggest number of incidences occurs between 1 and 3 years of age, ischemic strokes accounting for $50-60 \%$ of all strokes in children, half of which are idiopathic strokes [Klisowska et. al., 2012].

The ongoing disease process in patients with multiple sclerosis disrupts the functions and weakens the muscles which take part in swallowing. Dysphagia affects about $33 \%$ of patients. The risk of aspiration pneumonia, malnutrition and dehydration is identical as in other groups of patients. In anticipation of the weakening of the oral motor skills in the future, it is necessary to introduce active and passive exercises of the mouth and tongue as preventive and prophylactic measures. The aim of these exercises is to maintain muscle performance and the range of movements performed while eating. The progressing dysfunction process imposes modifications of the diet, meals of mushy or liquid consistency are gradually introduced, the food must be rich in protein and high-energy with an adequate quantity of vitamins and mineral salts [cf. Krupp, Rizvi, 2002; Kesselring, Beer, 2005]. 
Dysphagia is the second possible symptom of pseudobulbar palsy. The swallowing reflex is controlled by the centres located in the brain stem. Pseudobulbar palsy occurs in, for instance, Parkinson's disease, Alzheimer's disease, amyotrophic lateral sclerosis, multiple sclerosis, encephalitis, supranuclear palsy, brain tumors (the cerebellopontine angle), Binswanger's disease, Behçet's disease as well as some hereditary diseases and congenital defects. The symptoms of pseudobulbar palsy may also occur as a result of treatment of some diseases and complications of systemic or infectious diseases [Hamerlińska, Grądzka, 2017].

The stage of chewing in patients requiring palliative care takes much more time and the reason for this may be the inefficiency of the lips and tongue. It is not infrequent that they are not capable of swallowing on their own. Then it is necessary to introduce alternative feeding in the form of percutaneous endoscopic gastrostomy or enteral feeding [Brola et al., 2013].

\section{Therapeutic recommendations for caregivers of people with dysphagia}

The state of the disease or disability in one family member is an issue of not only an individual but it also affects other family members and is a source of great stress [Białek, 2015]. The whole family is "entangled in a disease", which causes certain consequences for its functioning [Kawczyńska-Butrym, 1995]. The family often has to change the ways of spending free time, reduces social activities or travelling and its members are affected by sleeping or eating disorders. In addition, the family may experience changes in its financial situation [Kawczyńska-Butrym, 1995]. When the child is ill, the relations between the child and its parents and other family members get distorted. Sometimes the disease disorganizes the life of the family and leads to its breakdown, but it may be also a factor which unites and motivates it to cooperate out of concern for the good of the ill family member [Woynarowska, 2010, p. 11].

- It is generally agreed that home is the best place for the patient [de WaldenGałuszko, 2011]. In a situation of an illness the family provides the basic environment in which the patient stays as [Taranowicz, 2001]:

- it creates the physical space and conditions appropriate for the patient and the situation of being ill;

- it controls the course of the disease, observes its symptoms, gives the first diagnosis, performs simple caring and therapeutic activities, controls the patient's behaviour, puts the recommendations of specialists into practice;

- it is the connector between the patient and the outside world;

- it gives social and emotional support.

Dealing with families with children who suffer from a chronic disease, K. Bialic [2016] analyzed the whole range of activities performed by parents, dividing them 
into three categories. The first one includes caring and therapeutic activities aimed at creating proper conditions of development and treatment as well as satisfying the child's needs, and the most important of them include: ensuring medical care and assistance and putting the recommendations of doctors into practice; providing the child with prescribed drugs and other medications as well as their suitable use; ensuring a suitable diet, resting and sleeping conditions; constant monitoring of the well-being and providing adequate assistance during attacks of the disease; satisfying emotional needs in the best possible way and showing emotional support in moments of suffering, pain and fear.

The second category includes educational and therapeutic activities aimed at supporting the child's development and shaping dispositions allowing to gain personal and social independence as well as fulfillment of the child's desires and interests. They include: developing personal and social independence of the child to the best of its capacity; developing in the child self-realization abilities in different forms of activity which are not a contraindication in the given condition; shaping positive features of character in the child; reducing and eliminating disorders in child's development caused by the illness; providing the child with the opportunity to be educated in such forms and directions which are the most suitable for the child.

The third category comprises rehabilitation activities whose aim it to improve the health and general motor skills, such as performing therapeutic exercises in accordance with recommendations of specialists and providing the patient with the necessary rehabilitation aids; teaching self-care activities and self-control which ensure protection from factors and situations which are detrimental to the patient's health, quick recognition and independent prevention of attacks and some disease conditions, observing the diet, adjusting the right amount of physical effort and movement; making efforts to ensure health resort rehabilitation [Bialic, 2016, p. 139].

The family helps in rehabilitation of the ill and disabled. This support is of great importance in a situation when swallowing disorders occur. Doing exercises aimed at facilitating the eating functions should be interwoven into the everyday functioning of the family not only when the therapist pays a visit. Besides, it was also mentioned that the family takes care of the patient's diet. Due to the patient's psychomotor disability the family helps do the shopping, prepares food and serves it. Nowadays there are many speech therapy aids, such as: vibrators, tongue-depressors, teethers, spoons which may be used in everyday exercises which facilitate the activity of swallowing. In addition, it is worth trying anyway not to exclude the person with swallowing disorders from eating meals together or taking part in family meetings because of the difficulty in question. It is possible to prepare a party in such a way that also the patient may enjoy it for a while to the best of their psychophysical abilities.

As it was said before it is natural that it is the family that will support the person with a disability accompanied by swallowing disorders. 
It is advisable that persons taking care of their family members with swallowing disorders know the basic principles of rational nutrition [cf. Biernat, 2003; Ryżko, Socha, 2010; Bojanowska, Ciołek, Czeczko, 2015]:

- covering the body's total demand for energy and essential nutrients;

- meals eaten regularly normalize metabolism;

- children should be provided high-quality proteins, carbohydrates and fats in the proportions $12-15 \% / 50-60 \% / 25-30 \%$, yet in the case of proteins the demand varies depending on age, body weight, metabolic condition and intensity of growth and regeneration of the body;

- sources of proteins include products of animal and plant origin;

- sources of fat include butter, lard, beef tallow, olive oil and all kinds of oils;

- sources of carbohydrates include wholegrain products (bread, groats, rice, bran), brown rice, buckwheat, oat bran, corn flour), fruit and vegetables;

- purchased products should contain a lot of vitamins, calcium, phosphorus and iron;

- it is important to drink large quantities of still water, especially in the summer and in the heating season;

- the salt intake should be reduced;

- setting the menu and preparing meals together are a good incentive to eat;

- the so-called unhealthy food should be completely eliminated from the diet;

- patients should be provided with the opportunity to have some physical activity, preferably in the open-air which should be suited to the psycho-physical possibilities of the patient, which in turn will improve the appetite.

Before a meal is prepared, each patient with difficulty in swallowing should be examined in order to determine which food consistency is safe for them and does not carry a risk of complications. It is possible to distinguish the following types of food consistency [Chmielewska et al., 2016]:

- a blended diet - a homogeneous consistency with a smooth structure, food may be eaten from a cup or with a spoon, it does not require biting or chewing;

- a pureed diet - a homogenous consistency, with no lumps, it may not be sticky, usually eaten with a spoon or a fork, it also does not require biting or chewing;

- a soft diet and a moist food - it has a consistency which is easy to squash with the fork, eaten with a fork or a spoon;

- a soft diet - its consistency does not require a knife to cut, eaten with a fork or a spoon, it is necessary to chew the food before swallowing, which is why it requires good performance and strength of the tongue to form a bolus in the oral cavity;

- a normal diet without any exclusions - everyday ordinary food.

Thicker and homogenous consistency makes the process of swallowing easier and safer. Liquids move in the direction of the esophagus very quickly, the risk of aspiration or penetration increases in patients with difficulty in swallowing, e.g. with 
elevation of the larynx. This is why it is recommended to give patients with dysphagia food and liquids of homogenous thick consistency, moist and at the same time not sticky. Thickened food and liquids allow some time for physiological swallowing reflex, the patient does not lose control over the content in the mouth and work of muscles involved in the process of chewing and swallowing. Hence the consumption of solid food of heterogeneous structure (e.g. goulash with meat, broth with noodles) increase the risk of dysphagia. Water in the food becomes "drained" quicker than the solids which require longer treatment and creation of the bolus in the oral cavity. Both water and solid food increase the risk of aspiration.

Parents of children or careers should not worry if the meals are served in the form of "mush" as mixed products give a greater guarantee of safe consumption and are easier absorbed. In addition, children may have problems with products of diversified texture which they did not know before. What is more, the ability to feel flavours may be delayed in some children. In turn, some children may be physically addicted to certain foods and in a situation of their complete exclusion from the diet they may suffer from withdrawal symptoms manifested by increased irritability, anger, and sometimes also attacks of fury. Temporary developmental regression may even occur in some situations [Compact, Laake, 2015]. Feeding, particularly in children, may be accompanied by the negative reaction of withdrawing the tongue or not opening the mouth which become a habit if they are perpetuated for months or years. Such an incorrect pattern later causes difficulty in eliminating it. In addition, feeding with the bottle for too long distorts the physiological "chewing-biting-swallowing" mechanism [Sołtys, 2016].

There are some guidelines necessary while feeding persons with dysphagia which contribute to safer consumption of meals and which may be used by their family or carers. They include [Fraser, Steele, 2012; Dzierżanowski, Rydzewska, 2017]:

- keeping the right body posture while feeding: the sitting position, with the straight neck and the chin drawn to the chest (this prevents aspiration); in patients with paresis it is necessary to turn the head to the paretic side, the turn "will close the larynx";

- after the meal the patient should remain in a high position for at least 15-30 minutes;

- the consistency of food should be adjusted to the possibilities of the patient, served in small portions; it is necessary to control chewing and swallowing at all times and check if the bite is not too big and if it does not make the patient choke;

- it is necessary to avoid food which is powdery or crumbling (biscuits, cakes, bread) as it may make the patient choke;

- before and during the meal it is necessary to check the denture fixing (if the patient has them) so as to prevent them from moving in a dangerous way while feeding; 
- both solid food and liquids have to have a distinct flavour (sensorial simulation of the oral cavity) and the right temperature;

- it is always necessary to check the patient after feeding if there is nothing left in the oral cavity; it is necessary to clean the teeth and the oral cavity after the meal;

- the patient is asked to do movement exercises of the lips, tongue, larynx and mandible during the daily hygiene similar to exercises with the physiotherapist or speech therapist; in addition breathing exercises are recommended.

Even if all the rules and principles are observed, aspiration and/or choking may still occur. In this event immediate reaction is necessary as longer obstruction of the respiratory system causes death. If there is liquid in the respiratory tract, it will be the easiest to lower the head below the line of the shoulders, the child should be put over the knee and patency of the respiratory system may be restored by hitting the child on the back in the interscapular region with the hand, using the gravitation force. The problem is more complicated in older persons, it is best to stand behind that person, lean the thorax forward and restore the ability to breathe by hitting the interscapular region. In the case of choking the action is similar as that used in order to get rid of a foreign body (a bite of food). In addition, the Heimlich maneuver may be performed in the case of adults, consisting in an abrupt thrust from the back of the lower region of the chest and epigastrium and emptying the respiratory tract. In a situation of persistent closure of the respiratory tract, it is necessary to call for medical help immediately ${ }^{2}$.

\section{Summary}

Safe food intake represents a major challenge both for carers and teams of therapists dealing with health improvement of patients with difficulty in swallowing. This is why cooperation of the family, carers and therapists is so important. Mutual interdisciplinary communication is aimed at increasing the knowledge and access to the most effective forms of assistance and preventing complications following incidents related to dysphagia in the subsequent years of their live. The family provides a person with swallowing disorders not only with moral, information and social support but also care and rehabilitation assistance [Bialic, 2016].

2 It is worthwhile for caregivers to stay in touch with physiotherapists and speech therapists. Professionals can support the rehabilitation process with appropriate swallowing maneuvers, which can then be repeated with the support of caregivers. 


\section{References}

Ahearn W.H., 2001, Help! My son eats only macaroni and cheese: Dealing with feeding problems in children with autism, [in:] C. Maurice, G. Green, R.M. Foxx (eds.), Making a difference. Behavioral Intervention for Autism, Austin: PROED, pp. 51-73.

Arvedson J.C., 2013, Feeding children with cerebral palsy and swallowing difficulties, "European Journal of Clinical Nutrition", no. 67, pp. 9-12.

Bialic K., 2016, Wsparcie społeczne rodziny z dzieckiem przewlekle chorym, “Seminare”, vol. 37, no. 1, pp. 131-142.

Białek K., 2015, Rodzina pod wpływem choroby jako stresora, "Państwo i Społeczeństwo", vol. XV, no. 4 , pp. $79-88$.

Biernat J., 2003, Żywienie, żywność a zdrowie, Wrocław: Wydawnictwo Astrum.

Bojanowska M., Ciołek A., Czeczko R., 2015, Żywienie a rozwój dziecka, Lublin: Towarzystwo Wydawnictw Naukowych Libropolis.

Boksa E., 2016, Dysfagia z perspektywy zaburzeń komunikacji językowej u dzieci i młodzieży $z$ niepetnosprawnościami sprzężonymi, Kraków: Wydawnictwo Libron.

Brola W., Kasprzyk M., Fudala M., Opara J., 2013, Palliative care for patients with multiplesclerosis, "Medycyna Paliatywna", vol. 5(2), pp. 41-47.

Bryant-Waugh R., Markham L., Kreipe R.E., Walsh B., 2010, Feeding and eating disorders in childhood, "International Journal of Eating Disorders", vol. 43, no. 2, pp. 98-111.

Calis E.A., Veugelers R., Sheppard J.J., Tibboel D., Evenhuis H.M., Penning C., 2008, Dysphagia in children with severe generalized cerebral palsy and intellectual disability, "Developmental Medicine and Child Neurology", vol. 50(8), pp. 625-630, http://dx.doi.org/10.1111/j.1469-8749 .2008.03047.x

Chatoor I., 2002, Feeding disorders in infants and toddlers: diagnosis and treatment, "Child and Adolescence Psychiatric Clinics of North America", no. 11, pp. 163-183.

Chmielewska J., Jamroz B., Sielska-Badurek E., Niemczyk K., 2016, Konsystencja i tekstura płynów i pokarmu jako ważny aspekt profilaktyki zachlystowego zapalenia płuc u pacjentów z dysfagia, [in:] M. Kurowska, J. Porayski-Pomsta, M. Przybysz-Piwko (eds.), Studia pragmalingwistyczne, Warszawa: Wydział Pedagogiki Uniwersytetu Warszawskiego, pp. 279-286.

Compact P., Laake D., 2015, Jak ugryźć ADHD, Warszawa: Grupa Wydawnicza Foksal.

Dzierżanowski T., Rydzewska G., 2017, Zaburzenia połykania u chorych objętych opieka paliatywna, "Medycyna Paliatywna", vol. 9(1), pp. 1-6.

Fraser S., Steele C., 2012, The effect of chin down position on penetration-aspiration in adults with dysphagia, "Canadian Journal of Speech-Language Pathology and Audiology", vol. 36(2), pp. 142-148.

Gadowska-Cicha A., Sieroń A., Cak M., 2004, Dysfagia - alarmujący objaw, "Chirurgia Polska", vol. 6, no. 2, pp. 101-107.

Ganesh R., Janakiraman L., Sathiyasekaran M., 2008, Plummer-Vinson syndrome: an unusual cause of dysphagia, "Annals of Tropical Paediatrics International Child Heath", vol. 28(2), pp. 143-147, http://doi.org/10.1179/146532808X302170

Hamerlińska A., Grądzka O., 2017, Zaburzenia czynnościowe kompleksu ustno-twarzowego w zespole rzekomoopuszkowym, "Neurolingwistyka Praktyczna", no. 3, pp. 129-141.

Hamerlińska-Latecka A., 2013, Dysfagia u pacjenta z choroba nowotworowa. Pomoc onkologopedy, "Forum Logopedyczne", no. 21, pp. 124-130.

Hamerlińska-Latecka A., Pyszora A., Wójcik A., 2013, Dysfagia, [in:] A. Wójcik, A. Pyszora (eds.), Fizjoterapia w medycynie paliatywnej, Warszawa: Wydawnictwo Lekarskie PZWL, pp. 129-143. 
Hoch T.A., Babbitt R.L., Farrar-Schneider D., 2001, Empirical Examination of a Multicomponent Treatment for Pediatric Food Refusal, "Education and Treatment of Children", no. 24, pp. 176-198.

Januś-Laszuk B., Czernuszenko A., Mirowska-Guzel D., Członkowska A., 2012, Wpływ powikłań na przebieg rehabilitacji u pacjentów po przebytym udarze mózgu, “Terapia”, no. 1, pp. 41-44.

Kawczyńska-Butrym Z., 1995, Rodzinny kontekst zdrowia i choroby, Warszawa: Centrum Edukacji Medycznej.

Kesselring J., Beer S., 2005, Symptomatic therapy and neurorehabilitation in multiple sclerosis, "The Lancet Neurology", no. 4, pp. 643-652.

Klisowska I., Dąbek A., Koprowski B., Kowalik M., Pidzik J., Machaj M., 2012, Udary mózgu u dzieci - czynniki ryzyka, objawy, rehabilitacja, "Pielęgniarstwo i Zdrowie Publiczne", vol. 2(4), pp. 311-314.

Klukowski K.S., Nowotny J., Czamara A., 2014, Słownik fizjoterapii, Warszawa: Wydawnictwo Lekarskie PZWL.

Krupp L.B., Rizvi S.A., 2009, Symptomatic therapy for underrecognized manifestations of multiple sclerosis, "Neurology", vol. 58, supplement 4, pp. 32-39.

Litwin M., 2009, Logopedyczna terapia zaburzeń połykania w chorobach neurologicznych, "Logopeda", vol. 1(7), pp. 126-138.

Narożny W., Szmaj M., 2014, Zaburzenia mowy w dysfagii, [in:] S. Milewski, J. Kuczkowski, K. Kaczorowska-Bray (eds.), Biomedyczne podstawy logopedii, Gdańsk: Harmonia Universalis, pp. 176-185.

Przeździęk M., 2016, Wspomaganie karmienia u dziecka z mózgowym porażeniem dziecięcym. Podstawowe zagadnienia, [in:] M. Kurowska, J. Porayski-Pomsta, M. Przybysz-Piwko (eds.), Studia pragmalingwistyczne, Warszawa: Wydział Pedagogiki Uniwersytetu Warszawskiego, pp. 177-187.

Riquelme L.F., Benjamin R.D., Tahhan H.J., Sandoval G., Alomari N., Soyfer A., 2016, Feeding/ swallowing disorders: Maintaining quality of life in persons with intellectual disability, "Journal of Intellectual Disability Diagnosis and Treatment", vol. 4(2), pp. 81-93, http://doi.org/10.6000 /2292-2598.2016.04.02.2

Riquelme L.F., Soyfer A., Engelman J., Palma G., Stein L., Chao J., 2008, Understanding oropharyngeal dysphagia: from hospital to home, "Home Health Care Management \& Practice", vol. 20(6), pp. 462-473, http://dx.doi.org/10.1177/1084822308318178

Ryżko J., Socha P., 2010, Żywienie niemowląt, dzieci i młodzieży, [in:] M. Grzymisławski, J. Gawęcki (eds.), Żywienie człowieka zdrowego i chorego, Warszawa: Wydawnictwo Naukowe PWN, pp. 15-37.

Sołtys I., 2016, Wpływ typu karmienia na rozwój wzorców artykulacyjnych. Przeciwdziałanie zaburzeniom w wypadku karmienia sztucznego - zadania logopedy, [in:] M. Kurowska,

J. Porayski-Pomsta, M. Przybysz-Piwko (eds.), Studia pragmalingwistyczne, Warszawa: Wydział Pedagogiki Uniwersytetu Warszawskiego, pp. 169-176.

Starosta M., Redlicka J., Brzeziański M., Niwald M., Miller E., 2016, Udar mózgu - ryzyko niepełnosprawności oraz możliwości poprawy funkcji motorycznych i poznawczych, "Polski Merkuriusz Lekarski”, vol. XLI(241), pp. 51-54.

Taranowicz I., 2001, Rola rodziny w opiece nad człowiekiem przewlekle chorym. Rodzina w czasach szybkich przemian, "Roczniki Socjologii Rodziny", no. XIII, pp. 209-228.

Walden-Gałuszko K. de, 2011, Psychoonkologia w praktyce klinicznej, Warszawa: Wydawnictwo Lekarskie PZWL.

Woynarowska B., 2010, Edukacja zdrowotna, Warszawa: Wydawnictwo Naukowe PWN. 


\section{Abstract}

The article presents the process of eating, and then describes dysphagia: its causes, classification and symptoms. The authors presented in the article selected diseases with which dysphagia coexists. The aim of the text is to indicate activities that can be used by caregivers of people with dysphagia in their daily care and therapy.

Streszczenie

W artykule przedstawiono proces jedzenia, a następnie dokonano opisu dysfagii: jej przyczyn, klasyfikacji oraz objawów. Autorzy ukazali wybrane schorzenia, z którymi dysfagia współwystępuje. Celem tekstu jest wskazanie czynności, które mogą być wykorzystywane przez opiekunów osób z dysfagią w codziennej pielęgnacji i terapii. 